\title{
Countering the Unverified Health Related Information
}

\author{
Djoko Setyabudi ${ }^{1}$, Tandiyo Pradekso ${ }^{2}$, S. Rouli Manalu ${ }^{3}$ \\ \{srmanalu@live.undip.ac.id ${ }^{3}$ \} \\ Universitas Diponegoro, Indonesia ${ }^{1,2,3}$
}

\begin{abstract}
The article is intended to offer the strategy to tackle the wrong and unverified information related to health issues. It is based on the data of a survey in East Java, the province with the second largest population in Indonesia, and the second largest economic in the country. The data shows that people in East Java admitted that they were expose to many incorrect and unverified health information, through various channels, such as personal chatting applications, mainstream/conventional media, and social media. The survey revealed that people responded differently to unverified health information. Some found clarity, but others felt anxious. The fact that people think they can get clarity though the information from social media and the Internet, are not sufficiently verified is upsetting. Trusting untested or clinically unproven health information can be harmful and dangerous. A way to counter the propagation of untested health information or unverified information sources is to use the same information channels to distribute the guidance to inform people how to identify the wrong and untested health information. And, by the same measure it could also empowering people to fight against such false information.
\end{abstract}

Keywords: Unverified Information, Media Literacy, Health Information.

\section{Introduction}

Stream of information is rapidly flowing over society through internet, social media, communication apps, and by word of mouth. The stream carried various kind of information, real information or true information, misinformation, false information, and fake information (hoax) that are colliding or even tied together. It is difficult for people in general to verify the fake and false information, yet for some it is quite clear because of the weird and unreasonable features of its content. Since the aftermath of the 2019's general election, where the circulation of political fake information is declining, the health false or fake information are remaining milling over the social media and chatting applications such as WhatsApp or Line. Some of them are dangerous, and the rest are just wasting one's time for nothing.

Inaccurate information might result from either a deliberate attempt to deceive or mislead (disinformation), or an honest mistake (misinformation). Either way, incorrect information spread out. Clearly, "authenticating and verifying the integrity of a document is .... Simply obtaining (and using) a copy of document. Some people are made mistake (honest mistake) that produce misinformation distributed along their networks and groups. Yet some other people made the disinformation for some personal or organizational objectives. It is produced in bad purposes and intentions. CNN Indonesia said, 800 sites are indicated to spread inaccurate information (hoax) and hate speech [1]. Public usually do not realize that inaccurate information can be designed by any purpose to set people in jeopardy. Both misinformation or 
disinformation have the capacity of triggering difficulties to society [2]. In the political fields, political disinformation or misinformation is responsible for many occasions of social split [3].

Social split will drain the entire community social potential for arguing each other of their point of view. In this situation, the cyberspace will be the virtual battle field for the competing parties. Each and every party will try to defend their stand point and in the same time, looking for opportunities to strike their opponents. When general election was over, people return to everyday routine as usual, yet the disinformation or misinformation flow are not paused. Those kinds of information are still in business, and health related false information is one of the most important among that inaccurate information.

The official website of the Ministry of Communication and Information stated that there are 1.731 hoax since August 2018 to April 2019 identified, verified, and validated by AIS Team of the Ministry of Communication and Information. Political hoaxes is dominant with 620 items. Second place is Governmental hoaxes by a number of 210 items. And followed by health hoaxes (200 hoaxes), then hates speech, criminals hoaxes, and the rest are religion issues, disasters, myths, international issues, and miscellaneous [4]. Fernandus, Chief of Public Relations of the Ministry of Communications and Informatics assert that by August 18 of 2019, there are more than 300.000 hoax URL that will lead us to Papua issues, and "I cannot imagine if our brothers will exposed by these hoaxes. Particularly those provocative agitations that will hurt their heart" [5]. Many people believe the information without clarifying them first. According to PWI survey in 2017, Indonesian people did not understand the health content thoroughly, but they tend to share it immediately. Health related unclarified information were the most information to be shared. Health related false information was 27 percent out of 1000 hoax samples collected since February 2016 until February 2018. Political hoax was in the second place, followed by entertainment information (15\%) and the rest are businesses and miscellaneous information. The distribution of those hoax is simply because the sender thought it was very important for their networks, even though they did not have any capacity to justify whether it is valuable or false information, because or lack of knowledge and logic [6].

People distributed unverified information mostly because they did not have any motivation for risking their friends or networks, conversely, they wanted to share important information for their precious ones. The receivers felt special and believed the sender because of their relationship or sender's offline reputations. Most of the receivers would follow the message or even tried the recommendation in the message shared. It is very risky for receivers because even the sender does not have enough knowledge to verify the information logically or scientifically.

The survey of health-related information in East Java that was conducted by the Department of Communication of Diponegoro University, Semarang, revealed that medicine is the most exposed false information to the respondents. It's not surprising because medicine still an issue for common people in East Java $(38,2 \%)$. Many people frequently questioning the usage of certain medicine, its exact dosages, its benefits, its side effects, and the replacements. The second most exposed is disease (30,1\%). People in East Java seems more eager to enrich their understanding about disease. Most of them want to learn about the things that cause certain disease, and for avoiding it in their daily life. 


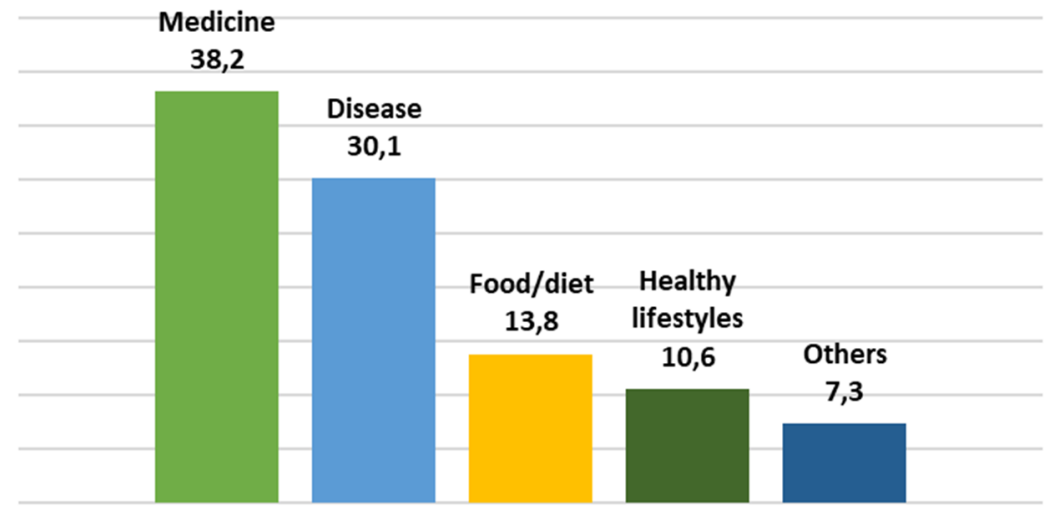

Fig. 1. Most exposed false information.

Of course, they finally aware that what they had been digest were false information after the trial were failed, found counter opinions, got new information, and many other reasons. The other issues that the respondents of the survey exposed from their communication networks are food, diet, and nutrition, healthy lifestyles, healthcare facilities, and health insurance.

The next important thing related to health false information is how the audience's response to those nature of information. Surprisingly, at the beginning many people felt that the exposed information regarding medicine and disease, even not sufficiently verified, were clarifying their curiosity and uncertainty $(33,1 \%$ and $25 \%$ out of those who exposed to false information). While people in general do not take the false health information seriously (felt so-so) in almost all of the issues, it is ironic that the feeling of anxiety is very low in 5 out of 6 issues. It is an indication of the vulnerability of the community in dealing with the rapid circulation of health-related false information.

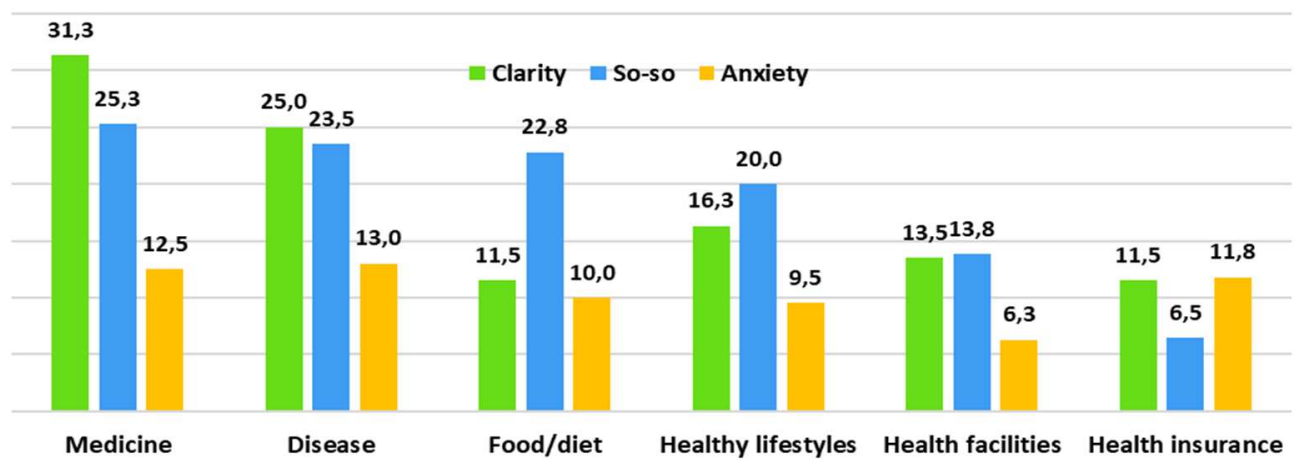

Fig. 2. Response to Health-Related Hoax. 


\section{Method}

Bearing in mind all the facts that people are immensely exposed to health-related false information while at the same time they are not sufficiently equipped with the knowledge and skill to tackle the issue, it is a necessity to develop means to empower people to survive the potential risk of those false information. A community-based campaign strategy will be established to deliver anti health related false information messages using the available online and offline networks.

\section{Results and Discussion}

The data shows that the distribution of health-related false information have some effect that differ from one to another. Some considerations come into attention in explaining the exposure of false information and their impact onto people. First is the social and cultural nature of the community, such as the case of East Java is the strong social bonding in the society. Second, East Java also has a more advanced internet network and smartphone penetration in their population. Third is the people's knowledge about social media and how news was producing by news institution or individual. All of them will shape people's attitude toward every information exposed them.

Within the context of social and cultural impact on attitude, the notions of conformity and self-concept are imperative. Conformity is the act of matching one's behavior to the responses of others. Conformity has been initiated to be an influential social phenomenon as people are often create to conform to the behaviors of others even when the actions of those other people run different to people own beliefs, such as in the classic experiments by Asch. Subsequent research has also proved that even our recalls are affected by exposure to the reminiscences of others. Deutsch and Gerard [7] made a distinction between informational and normative drives for conformity. Informational motivations are driven by a desire to infer reality in an exact way whereas normative motivations are based on the desire to obtain social agreement from others. More current research has largely upheld these findings. The summary by Cialdini and Goldstein [8], underlines the importance of conformity in gaining social approval, stating that "individuals often engage in ... conscious and deliberate attempts to the social approval of others, to build pleasing relationships with them, and in the process, to improve their self-esteem. Conformity offers such a chance".

The self-concept is an individual's group of beliefs about him or herself, usually reacting the question of 'who am I'? People tend to conceptualize themselves in accordance with dual basic aspects of human beings: agency and communion [7]. Agency represents such individual interests and values as self-assertion, self-improvement and self-esteem. Communion, on the other hand, is about social bonding, connections with others, cooperation and care for others [9]. Agentic individuals are dispositioned to show a more self-centered behavior and focus on differentiating themselves from others. Communal individuals, on the other hand, are more likely to be a part of a group and form social connections [10]. Cialdini and Trost [11] state that all individuals share a strong need to enhance the self-concept. This is done by behaving constantly with their statements, actions, beliefs, commitments and self-ascribed traits. One of the ways in which this shows itself is by the consumption by individuals of products that correspond with their self-thought as a means of self-expression [12]. Another is the way individuals behave and write online in response to comments from other internet users [7]. 
Confronting the stream of information, as stated above in self-concept, there are some people that are acted as "communal individual" who always have some concern to their society. They tend to distribute unverified information as long as they think it was very important to their society. At the same time, they do not have sufficient capability to verify the exposed information. When they think it is very important then they will distribute it to their network. Alternatively, people that tend to be "agentic individual" share some fake information for different motivation, that is they want to be considered as special individual with special knowledge in their society. They tend to present themselves as individual with different personality. For agentic individual, to share the shocking information related to health issues will strengthen their personal image, as they want to be the special one in their community or network.

Dealing with these types of potential attitudes within the society, a strategy to confront the propagation of health-related false information should be endorsed. The idea is to develop a community based social campaign along the existing networks available, whether online or offline. In the online path, the program will establish groups of online neighborhoods (with a thought to $R T / R W /$ village levels) that are going to be connected to sources of health experts, such as medical doctors, public health officers, paramedics, pharmacists. Connection will also involve communication experts, especially in the field of digital literacy, journalism, and strategic persuasion. The groups could also utilize the community clinics (Puskesmas) as hubs of periodic discussions and trainings. All the experts will be crafting the content of the campaign, that in turn will be deploy into the network. The offline networks will exploit the existing community meetings that traditionally conducted at the neighborhood level and village level. This type of meeting is effective to suppress the potential spread of harmful information. The offline path could also integrate the campaign into the existing health campaign such as the "barefoot doctors" program, in which paramedics or doctors visiting the villages, communities, and neighborhoods to provide the health-related services and supports. These medical doctors or paramedics could detect any discourse of health-related false information among their clients before straightening them.

\section{Conclusion}

As people understand how news and information were produced, they will be more aware to the possibility that the news is inaccurate. Therefore, people should be more cautious to the accuracy of every information exposed. People are recommended to cross check the health information to any trustworthy sources online or offline, before they make any decision regarding the information. Along with the growing comprehension to the issue of healthrelated false information, a strategic social campaign to counter that false information should be carried out. The campaign should simultaneously utilize both the online and offline networks.

\section{References}

[1] A. B. Permata, “Ada 800 Ribu Situs Penyebar Hoax di Indonesia," CNN Indonesia, 2016. .

[2] B. Rifa'i, "Akibat Hoax, Terjadi 6 Kasus Orang Gila Dikeroyok di Banten," detiknews, 2018.

[3] A. B. Wahid, "Polri Antisipasi Efek Hoax Agar Tak Seperti Lebanon dan Suriah," detiknews, 2019. . 
[4] Kominfo, "Temuan Kominfo Hoax Paling Banyak Beredar di April," Kominfo.go.id, 2019.

[5] Kominfo, "Kominfo: 300.000 Url Hoaks Terkait Papua Disebar di Internet," Kominfo.go.id, 2019.

[6] A. W. Putri, "Hoaks Kesehatan Bikin Penyakit Semakin Runyam," Tirto.id, 2019. .

[7] J. Colliander, “"This is fake news': Investigating the role of conformity to other users' views when commenting on and spreading disinformation in social media," Comput. Human Behav., vol. 97, pp. 202-215, 2019.

[8] R. B. Cialdini and N. J. Goldstein, "Social influence: Compliance and conformity," Annu. Rev. Psychol., vol. 55, pp. 591-621, 2004.

[9] M. Yang et al., "Comparative evaluation of the AdvanSure Mycobacteria GenoBlot assay and the GenoType Mycobacterium CM/AS assay for the identification of non-tuberculous mycobacteria," J. Med. Microbiol., vol. 65, no. 12, pp. 1422-1428, 2016.

[10] J. S. Wiggins, "Agency and communion as conceptual coordinates for the understanding and measurement of interpersonal behavior.," 1991.

[11] R. B. Cialdini and M. R. Trost, "Social influence: Social norms, conformity and compliance.," 1998.

[12] K. A. Braun, R. Ellis, and E. F. Loftus, "Make my memory: How advertising can change our memories of the past," Psychol. Mark., vol. 19, no. 1, pp. 1-23, 2002. 